Terbit online pada laman web jurnal : http://teknosi.fti.unand.ac.id/

\title{
Perancangan Sistem Informasi Penggajian Terintegrasi Berbasis Web (Studi Kasus di Rumah Sakit St. Elisabeth)
}

\author{
Cosmas Eko Suharyanto ${ }^{a}$, Joni Eka Chandra ${ }^{b}$, Fergyanto E Gunawan ${ }^{c}$ \\ ${ }^{a, b}$ Universitas Putera Batam, Jl. R. Soeprapto Mukakuning, Batam 29434, Indonesia \\ ${ }^{c}$ Universitas Bina Nusantara, Jl. Kebon Jeruk Raya No.27, RT.1/RW.9, Jakarta 11530, Indonesia
}

\begin{tabular}{|c|}
\hline INFORMASI ARTIKEL \\
\hline $\begin{array}{l}\text { Sejarah Artikel: } \\
\text { Diterima Redaksi: } 15 \text { Juni } 2017 \\
\text { Revisi Akhir: 27 Juli } 2017 \\
\text { Diterbitkan Online: } 31 \text { Agustus } 2017\end{array}$ \\
\hline KATA KUNCI \\
\hline $\begin{array}{l}\text { Sistem Informasi } \\
\text { Payroll } \\
\text { Web-based }\end{array}$ \\
\hline KORESPONDENSI \\
\hline $\begin{array}{l}\text { Telepon: +62 } 85668174530 \\
\text { E-mail: costmust@gmail.com }\end{array}$ \\
\hline
\end{tabular}

\section{A B S T R A C T}

This study aims to analyze and provide a solutive proposal to the payroll system at St. Elisabeth Hospital which is not implemented an integrated system and still uses manual calculations. Redundancy issues are a major issue, including waste of storage, inaccurate overtime calculations, as the effects of unintegrated systems. By Using Database Management System and designing web based interface then payroll system become more effective and efficient. Integrated system solves data redundancy problems and integrates payroll sub-sub systems. Integrated process allows for the integration of reports with fast processing and minimizing problems caused by human error. The effectiveness and efficiency of the payroll system will have an impact on optimal hospital services.

\section{PENDAHULUAN}

Pengolahan dan manajemen data, sebenarnya bukan hal baru, sejak jaman dahulu menusia terus berusaha mengembangkan tehnik-tehnik mengolah data. Hal yang membedakan dengan kondisi saat ini adalah adanya konvergensi antar kemajuan segala bidang yang saling berpengaruh.

Demikian juga pada bidang Pelayanan Sosial Rumah Sakit, perkembangan teknologi kesehatan dewasa ini, telah mempengaruhi sistem dan manajemen pengelolaan pelayanan sosial. Perkembangan teknologi di bidang kesehatan akan mampu ber-sinergi dengan baik apabila unsur-unsur pendukung lainnya juga mengimbanginya dengan kemajuan dibidangnya; misalnya perkembangan Teknology Informasi saat ini memampukan keseluruhan manajemen pengolahan data dapat dioptimalkan efektivitas dan efisiensinya.

Rumah Sakit St. Elisabeth Batam adalah sebuah unit pelayanan sosial publik yang didirikan oleh para Misionaris Fransiskan St. Elisabeth (Kongregasi FSE). Dimulai pada Februari 1985 dengan membuka Balai Pengobatan. Seiring dengan perkembangan
Pulau Batam sebagai kawasan industri dengan arus migrasi penduduk yang tinggi [1], pada tahun 2001 Balai Pengobatan ini menjadi Rumah Sakit St. Elisabeth Batam dengan berbagai kemajuan fasilitasnya.

Namun, sistem yang sedang berjalan masih manual. Data karyawan di-input secara manual, perhitungan gaji, lembur, potongan, absensi, pajak, pinjaman dan lain-lain dihitung tanpa penggunaan Database Management System yang dapat mengakibatkan kerangkapan data (redundancy).

\section{TINJAUAN PUSTAKA}

\subsection{Sistem Informasi}

Secara etimologis, sistem informasi berasal dari kata "sistem" dan "informasi". Sistem adalah seperangkat komponen yang saling berinteraksi, saling terkait, saling bergantung yang berfungsi secara keseluruhan untuk mencapai tujuan tertentu. Sistem yang efektif harus sinergis. Sistem biasanya beroperasi di lingkungan yang berada di luar dirinya sendiri. Sistem juga dapat didefinisikan sebagai kombinasi antara personil, bahan, fasilitas dan peralatan yang bekerja sama untuk mengubah masukan 
(input) menjadi keluaran (output) yang berarti dan dibutuhkan [2]. Pada tingkat yang paling mendasar, informasi adalah propagasi sebab dan akibat dalam sebuah sistem. Informasi disampaikan baik sebagai isi pesan atau melalui pengamatan langsung atau tidak langsung terhadap apapun. Hal yang dirasakan dapat ditafsirkan sebagai pesan tersendiri, dan dalam pengertian itu, informasi selalu disampaikan sebagai isi pesan, oleh karena itu informasi adalah sebuah pesan yang memiliki berbagai pengertian yang berbeda tergantung pada konteksnya [3].

Terdapat banyak sekali persepektif teori tentang sistem informasi. Perbedaan pandangan timbul oleh berbagai latar belakang dan sudut pandang orientasi disiplin ilmu [4]. Sistem informasi menurut O'Brien \& Marakas dalam [5] dapat berupa kombinasi orang, perangkat keras, perangkat lunak, jaringan komunikasi, sumber data, dan kebijakan serta prosedur yang mengatur, mengambil, mengubah, dan menyebarkan informasi dalam suatu organisasi.

Beheshtiyan dalam [6], mengatakan bahwa sistem informasi meliputi seperangkat individu, data / informasi, metode, perangkat lunak, perangkat keras dan komunikasi yang aktif dalam organisasi untuk memberikan informasi yang berguna untuk mempercepat dan mempermudah kegiatan, menciptakan koordinasi dan pengendalian, membantu analisis masalah, mendukung pengambilan keputusan, serta mengurangi ketidakpastian dalam pengambilan keputusan.

\subsection{Basis Data}

Basis data atau database adalah kumpulan data terstruktur. Agar dapat menambahkan, mengakses, dan memproses data yang tersimpan dalam database komputer, dibutuhkan sistem manajemen basis data (database management system) [7].

Dalam pengembangan perangkat lunak tradisional yang memanfaatkan pemrosesan file, setiap kelompok pengguna menyimpan file-file-nya sendiri untuk menangani aplikasi pengolahan datanya masing-masing. Hal ini mengakibatkan adanya kerangkapan data atau disebut dengan redundancy.

Redundansi dalam proses penyimpanan data yang terjadi berkalikali dapat mengakibatkan beberapa masalah. Pertama, ada kebutuhan untuk melakukan pembaruan logis tunggal, misalnya seperti memasukkan data pada siswa baru beberapa kali: satu kali untuk setiap file tempat data siswa direkam. Hal ini menyebabkan duplikasi data. Kedua, ruang penyimpanan terbuang ketika data yang sama disimpan berulang kali, dan masalah ini mungkin serius untuk database yang besar. Ketiga, file yang mewakili data yang sama mungkin menjadi tidak konsisten. Hal ini bisa terjadi karena update diaplikasikan pada beberapa file tapi tidak untuk file yang lain [8].

\section{3. $M y S Q L$}

Salah satu contoh database management system adalah MySQL. MySQL adalah database open source terpopuler di dunia. Dengan kinerja, kehandalan dan kemudahan penggunaan yang terbukti, MySQL telah menjadi pilihan database terdepan untuk aplikasi berbasis web, yang digunakan oleh properti web profil tinggi termasuk Facebook, Twitter, YouTube, Yahoo! dan banyak lagi [9].

Kata "SQL" dari "MySQL" adalah singkatan dari "Structured Query Language". SQL adalah bahasa standar yang paling umum digunakan untuk mengakses database. Bergantung pada lingkungan pemrograman yang kita pakai, kita bisa memasukkan SQL secara langsung (misalnya, untuk men-generate laporan), memasukkan pernyataan SQL ke dalam kode yang ditulis dalam bahasa lain, atau menggunakan API khusus yang dapat menyembunyikan sintaks SQL [7].

\subsection{PHP: Hypertext Preprocessor (PHP)}

PHP adalah bahasa scripting yang populer yang sering digunakan untuk pengembangan web. Dibuat pada tahun 1994 oleh Rasmus Lerdorf, penjelmaan pertama PHP adalah sekumpulan binari Common Gateway Interface (CGI) sederhana yang ditulis dalam bahasa pemrograman $\mathrm{C}[10]$.

PHP 3.0 adalah versi pertama yang sangat mirip dengan PHP seperti yang ada saat ini. Pada musim dingin tahun 1998, tak lama setelah PHP 3.0 diluncurkan secara resmi, Andi Gutmans dan Zeev Suraski mulai mengerjakan penulisan ulang inti PHP. Tujuan desain adalah untuk meningkatkan kinerja aplikasi yang kompleks, dan memperbaiki modularitas basis kode PHP. Mesin baru, yang dijuluki 'Zend Engine' (terdiri dari nama depan mereka, Zeev dan Andi), memenuhi tujuan desain ini dengan sukses, dan pertama kali diperkenalkan pada pertengahan 1999. PHP 4.0, berdasarkan mesin ini, dan digabungkan dengan berbagai macam tambahan fitur baru, resmi dirilis pada Mei 2000, hampir dua tahun setelah pendahulunya. PHP 5 dirilis pada bulan Juli 2004 setelah pengembangan yang panjang dan beberapa prarilis. Hal ini terutama didorong oleh intinya, Zend Engine 2.0 dengan model objek baru dan puluhan fitur baru lainnya [10].

\subsection{Data Flow Diagram (DFD)}

Alat utama untuk merepresentasikan proses komponen sistem dan arus data di antaranya adalah data flow diagram (DFD). Data flow diagram menawarkan model grafis logis dari arus informasi, mempartisi sistem menjadi modul yang menunjukkan tingkat detail yang dapat diatur. Ini secara ketat menentukan proses atau transformasi yang terjadi di dalam setiap modul dan antarmuka yang ada di antara keduanya [11].

Adapun keuntungan menggunakan DFD adalah meningkatkan pemahaman keterkaitan antara sistem dan sub-sistem, selain sebagai alat yang efektif dalam berkomunikasi dengan pengguna [2].

\subsection{Entity Relationship Diagram (ERD)}

ERD adalah jenis model basis data berdasarkan pengertian suatu entitas dunia nyata dan hubungan di antara mereka. Kita dapat memetakan skenario dunia nyata ke model database hubungan antar entitas. Model hubungan entitas ini menciptakan satu set entitas dengan atributnya, satu set konstrain dan relasi di antara keduanya [12]. 
Dalam paradigma Object Oriented (OO), diagram ekuivalen ini disebut object-relationship diagram (ORD atau O-R diagram) [2].

\subsection{Gaji}

Gaji atau upah adalah hak pekerja yang diterima dan dinyatakan dalam bentuk uang sebagai imbalan dari pemberi kerja kepada pekerja yang ditetapkan dan dibayar menurut suatu perjanjian kerja, kesepakatan, atau peraturan perundang-undangan, termasuk tunjangan bagi pekerja dan keluarganya atas suatu pekerjaan dan/atau jasa yang telah atau akan dilakukan [13]. Berdasarkan definisi di atas maka gaji bias dikatakan suatu bentuk balas jasa ataupun penghargaan yang diberikan secara teratur kepada seorang pegawai atas jasa dan hasil kerjanya. Gaji sering juga disebut sebagai upah, keduanya merupakan suatu bentuk kompensasi, yakni imbalan jasa yang diberikan secara teratur atas prestasi kerja yang diberikan kepada seorang pegawai.

\subsection{Pajak Penghasilan (PPh Pasal 21)}

Pengertian Pajak Penghasilan (PPh) Pasal 21 berdasarkan Peraturan Direktur Jenderal Pajak Nomor PER-32/PJ/2015 adalah pajak atas penghasilan berupa gaji, upah, honorarium, tunjangan dan pembayaran lain dengan nama dan dalam bentuk apa pun sehubungan dengan pekerjaan atau jabatan, jasa, dan kegiatan yang dilakukan oleh orang pribadi subyek pajak dalam negeri [14].

\section{ANALISIS SISTEM LAMA}

\subsection{Aliran Sistem Informasi yang Lama}

Langkah-langkah dalam merekam serta menyajikan data penggajian karyawan yang diterapkan pada Rumah Sakit St. Elisabeth Batam pada saat ini adalah sebagai berikut:

1) Bagian recurtment pada departemen HRD meng-input data karyawan yang baru masuk.

2) Kartu absensi dibagikan kepada clerk pada tiap departemen yang ada di bagian produksi.

3) Kartu absensi diantar clerk ke bagian payroll (penggajian) pada dept HRD dan akan di-input dan diproses.

4) Setelah diinput oleh bagian payroll maka laporan diantar ke bagian finance atau accounting untuk diperiksa.

5) Jika laporan sudah benar maka gaji akan diproses ke bank, tapi jika ada kesalahan maka laporan akan dikembalikan kebagian personalia untuk diproses ulang.

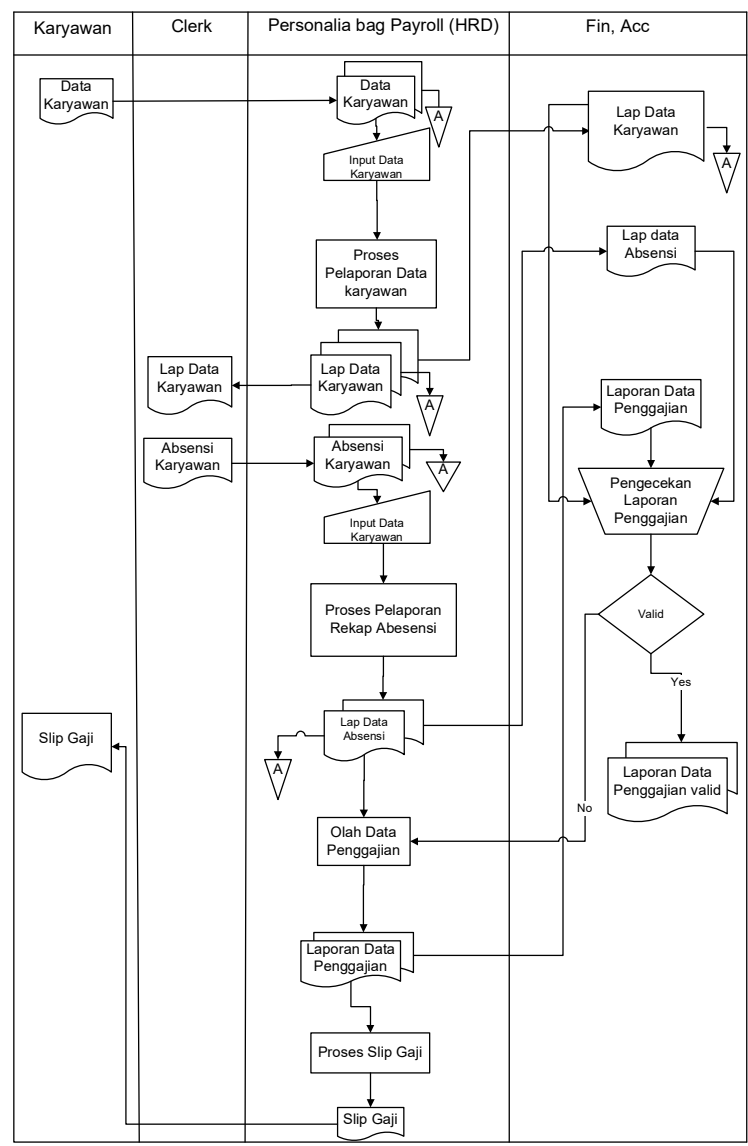

Gambar 1. Aliran Sistem Informasi yang Lama

\subsection{Permasalahan Sistem Lama}

Berdasarkan melakukan penelitian, tanya jawab, pengamatan serta analisis terhadap sistem informasi yang sedang berjalan pada objek yang diteliti, maka dapat ditemui beberapa masalah yang dihadapi yaitu :

1) Metode pencatatan serta pengolahan data karyawan masih menggunakan sebuah sistem yang tidak berbasis database yang dinilai tidak efisien dan efektif.

2) Akibat pengelolaan database tidak ada atau masih manual, maka sering terjadi redundansi data, yang selain berdampak pada efisiensi kerja juga berdampak pada pemborosan storage sumber daya komputer yang ada.

3) Kurangnya keakuratan dalam penghitungan jumlah overtime karyawan, karena masih menggunakan sistem manual yaitu menghitung dengan perkalian yang masih diinput sendiri karena bisa saja karyawan melakukan penghitungan yang salah, karena faktor kelelahan atau kelalaian. Hal ini sangat dimungkinkan mengingat manusia tidak bisa berpikir dengan baik saat kondisi tubuh mereka lemah.

4) Pengolahan sistem penggajian tidak terintegrasi antar sub sistem; data absensi di-input secara manual kedalam sistem penggajian dan laporan SPT PPh Pasal 21.

\subsection{Usulan Pemecahan Masalah}

Dari permasalahan yang timbul, maka beberapa hal dibawah ini dibutuhkan oleh Rumah Sakit St. Elisabeth dalam pembuatan sistem penggajian yang terintegrasi:

Cosmas Eko Suharyanto

227 
1) Perhitungan gaji karyawan berbasis database (DBMS) sehingga perincian gaji yang diterima karyawan dapat diketahui dengan jelas dan lebih akurat, serta dapat diakses sewaktu-watu dengan fasilitas search: berdasarkan NRP (Nomor Register Pegawai), nama awal ataupun nama akhir, status karyawan (kontrak atau permanen), jenis kelamin, tanggal masuk, umur, dll.

2) Integrasi laporan gaji dengan laporan-laporan pendukung; Laporan Pemotongan PPh21, Laporan Pemotongan Pinjaman, Koperasi dan atau Kantin, Laporan Perhitungan SPT Tahunan Pajak Penghasilan (PPh Pasal 21).

3) Web-based system, mengingat rumah sakit ini terdiri dari banyak cabang, baik dalam kota Batam sendiri maupun di luar Batam, maka untuk mendukung pengambilan keputusan manajerial yang terintegrasi dibutuhkan sistem berbasis web (web-based) yang akan memungkinkan integrasi, pengaksesan dan autentikasi global via internet.

\section{PERANCANGAN SISTEM}

\subsection{Aliran Sistem Informasi yang Baru}

Temuan-temuan pada analisis sistem yang lama menjadi dasar dalam penyusunan analisis sistem yang baru. Sekecil apapun berbaikan yang dilakukan akan mempengaruhi efisiensi dan efektivitas kinerja Rumah Sakit disatu sisi, sebaliknya perbaikan di salah satu sub sistem akan berdampak pada sub sistem yang lain untuk juga melakukan penyesuaian yang dibutuhkan.

Pada proses penggajian, sistem akan membaca database jam kerja karyawan dalam suatu waktu tertentu dan membaca database karyawan, setelah itu data diolah dan menghasilkan perhitungan gaji setiap karyawan, pembuatan slip gaji dan laporan SPT Tahunan. Rancangan masukan dan keluaran yang diperlukan dan disesuaikan dengan tingkat kebutuhan rumah sakit sesuai dengan peraturan pemerintah dan kebijakan internal Rumah Sakit St. Elisabeth.

Selanjutnya, dalam proses perencanaan sistem informasi, langkah awal sebagaimana telah dilakukan di awal yaitu mengidentifikasikan secara lengkap tujuan, sasaran maupun hambatan dalam organisasi. Perancangan sistem ini bertujuan untuk menciptakan sebuah sistem baru yang akan memberikan masukan solusi dari permasalahan yang terjadi. Aliran Sistem Informasi (ASI) yang baru menggambarkan arus informasi dari entitas yang ada (lih. Gambar 2).

Secara umum, perbaikan yang kami usulkan adalah adanya Database Management System (DBMS) untuk mengolah datadata penggajian, sedangkan entitas-entitas lain masih merujuk pada sistem lama. Dengan adanya DBMS ini maka memungkinkan integrasi data.

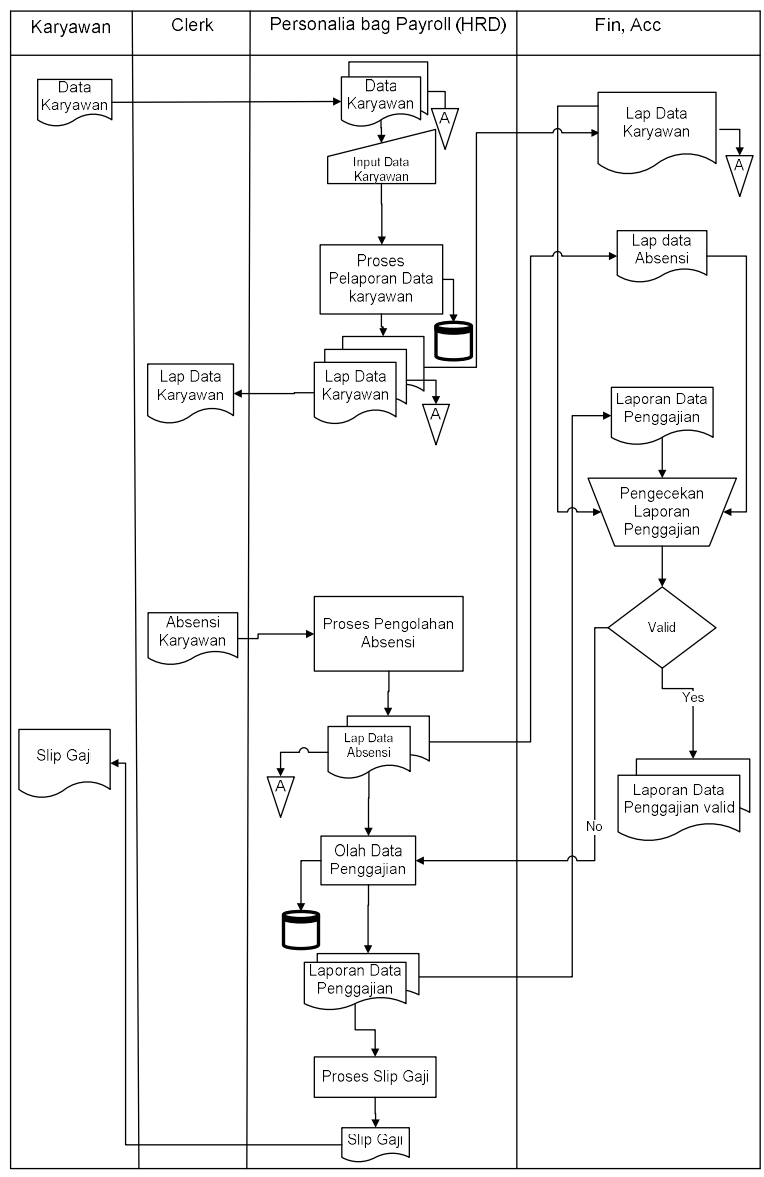

Gambar 2. Aliran Sistem Informasi yang Baru

\subsection{Diagram Konteks}

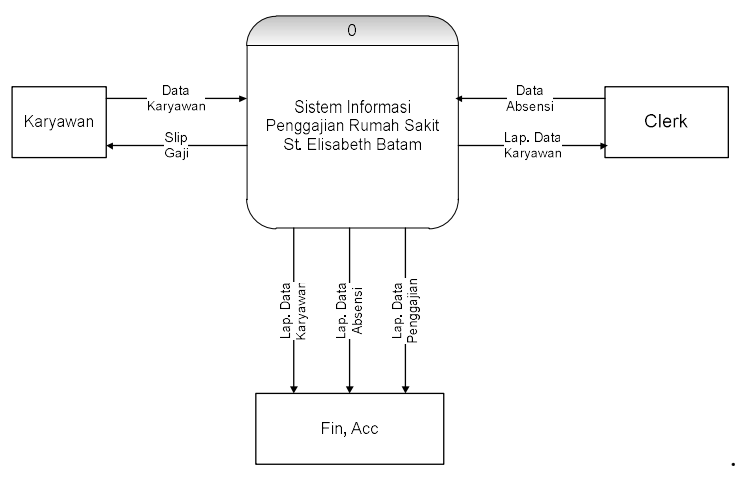

Gambar 3. Diagram konteks

Sesuai dengan gambar diagram konteks di atas, Entitas karyawan akan memberikan input kepada sistem berupa data karyawan dan karyawan akan mendapatkan keluaran dari sistem berupa slip gaji. Sistem akan memberikan keluaran berupa laporan data karyawan kepada entitas clerk dan entitas clerk akan memberikan masukan kepada sistem berupa data absensi karyawan. Sistem akan memberikan keluaran kepada entitas Finance, Accounting berupa laporan data karyawan, laporan data absensi serta laporan data penggajian. 


\subsection{Data Flow Diagram (DFD)}

Data Flow Diagram menggambarkan sistem sebagai jaringan kerja antar fungsi yang berhubungan satu sama lain dengan aliran dan penyimpanan data.

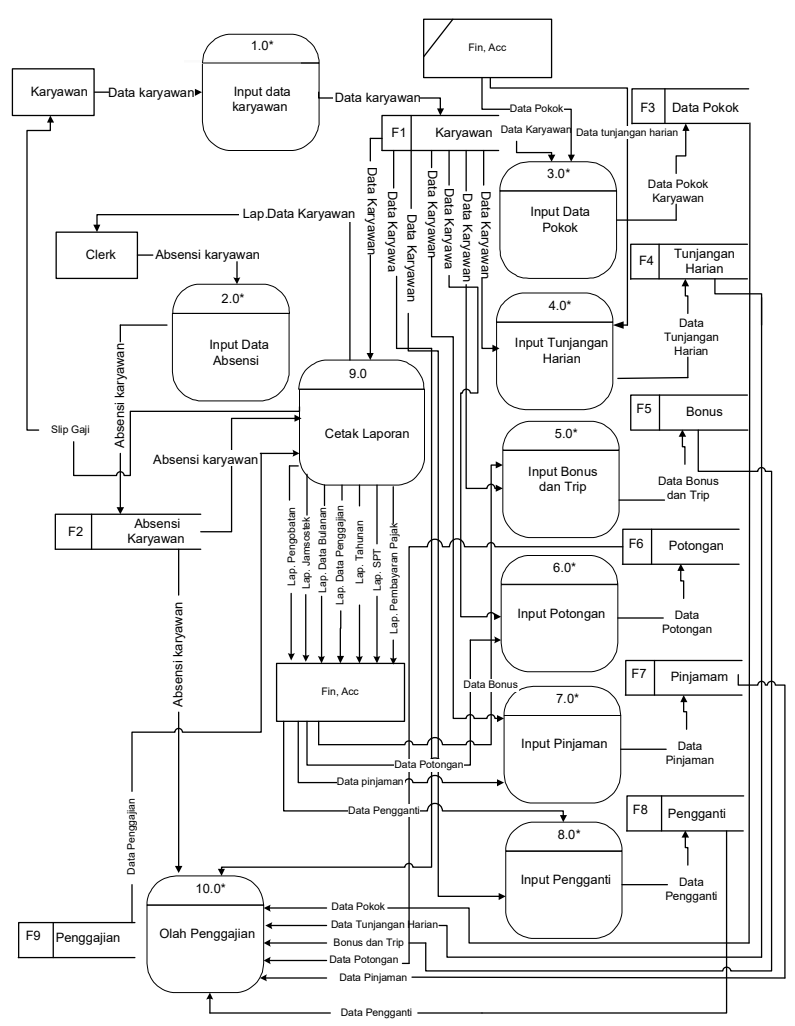

Gambar 4. Data Flow Diagram

Pada proses input data karyawan, karyawan akan melakukan proses input dan secara otomatis akan disimpan kedalam simpanan karyawan. Pada proses input data absensi, clerk akan memberikan data absensi karyawan kepada sistem lalu akan diinput dan akan disimpan kedalam simpanan absensi karyawan. Setelah itu akan dilakukan proses penggajian, data-data yang diperlukan akan diambil dari simpanan data karyawan dan simpanan data absensi dan akan disimpan kedalam simpanan penggajian. Setelah melakukan proses penggajian maka akan dilakukan proses cetak laporan dan semua laporan akan diberikan ke Fin, Acc setelah itu akan melakukan proses cetak slip gaji, data diambil dari simpanan Data Penggajian (payroll). Setelah itu slip gaji ini akan diberikan kepada karyawan. Demikian juga dengan laporan SPT kepada Lembaga Perpajakan, data-data akan diambil dan disimpan dari Data Penggajian. Laporan BPJS, Pengobatan, Laporan Pembayaran Pajak dan Laporan Tahunan Gaji sudah terintegrasi dan hanya mengambil data dari Data Penggajian, proses ini dapat dikembangkan untuk laporan-laporan yang dibutuhkan (lih Gambar 5). Penyesuaian tarif BPJS, PTKP, dapat dilakukan penyesuaian dengan mudah dengan disediakannya tabel-tabel terkait.

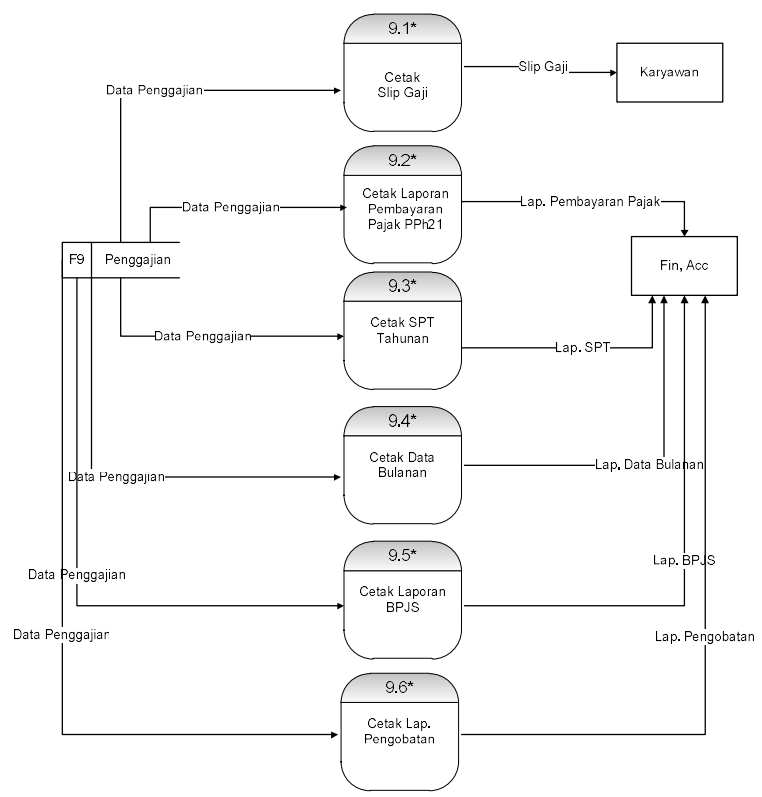

Gambar 5. Diagram Rinci

Diagram rinci digunakan untuk merinci disain sistem terdiri dari masukan, keluaran dan simpanan serta proses apa saja untuk memperoleh hasil yang semaksimal mungkin. Pada diagram rinci proses 9.0 diatas dijelaskan secara terinci proses pencetakan laporan. Data karyawan akan diambil oleh sistem dari simpanan data karyawan lalu akan dicetak laporan data karyawan untuk diserahkan kepada Entity Fin Acc. Data absensi karyawan akan diambil oleh sistem dari simpanan data absensi karyawan lalu akan dicetak laporan absensi karyawan untuk diserahkan kepada Entity Fin Acc, dan Entity Clerk. Data penggajian akan diambil oleh sistem dari simpanan data penggajian lalu akan dicetak laporan penggajian untuk diserahkan kepada Entity Fin Acc.

Secara detail proses keterkaitan fungsi pada data flow diagram dan diagram rinci dapat dilihat dalam Tabel Spesifikasi Proses berikut:

Tabel 1. Spesifikasi Proses

\begin{tabular}{|c|c|}
\hline $\begin{array}{l}\text { Proses } \\
1.0 .^{*}\end{array}$ & $\begin{array}{l}\text { Nama Proses: Input data karyawan } \\
\text { Masukan : Data karyawan } \\
\text { Keluaran : File karyawan } \\
\text { Proses : Input data Karyawan kemudian disimpan ke dalam } \\
\text { file karyawan }\end{array}$ \\
\hline $\begin{array}{l}\text { Proses } \\
2.0 .^{*}\end{array}$ & $\begin{array}{l}\text { Nama Proses: Input data absensi karyawan } \\
\text { Masukan : Data absensi karyawan } \\
\text { Keluaran : File absensi karyawan } \\
\text { Proses } \quad \text { :Input data absensi karyawan kemudian disimpan ke } \\
\text { dalam file absensi karyawan }\end{array}$ \\
\hline
\end{tabular}

\begin{tabular}{|c|c|}
\hline Proses & Nama Proses: Input Data Pokok \\
\hline 3.0.* & $\begin{array}{l}\text { Masukan : File Karyawan } \\
\text { Keluaran : File Data Pokok } \\
\text { Proses : Membaca database karyawan, input Tunjangan Tetap } \\
\text { per bulan, input kelas berobat, input dapat lembur atau tidak, input } \\
\text { nomor rekening, input status kerja. }\end{array}$ \\
\hline Proses & Nama Proses: Input Tunjangan Harian \\
\hline 4.0.* & $\begin{array}{ll}\text { Masukan } & \text { : File karyawan } \\
\text { Keluaran } & \text { : File Tunjangan Harian } \\
\text { Proses } & \text { : Membaca file karyawan kemudian input tunjangan } \\
\text { harian }\end{array}$ \\
\hline
\end{tabular}




\begin{tabular}{|c|c|}
\hline $\begin{array}{l}\text { Proses } \\
5.0 .^{*}\end{array}$ & $\begin{array}{l}\text { Nama Proses: Input Bonus dan Trip } \\
\text { Masukan : File karyawan } \\
\text { Keluaran : File Bonus dan Trip } \\
\text { Proses : Membaca file karyawan input jasa pelayanan, THR, } \\
\text { Insentif, Trip. }\end{array}$ \\
\hline $\begin{array}{l}\text { Proses } \\
6.0 .^{*}\end{array}$ & $\begin{array}{l}\text { Nama Proses: Input Potongan } \\
\text { Masukan : File Karyawan } \\
\text { Keluaran : File Potongan } \\
\text { Proses: Membaca file karyawan kemudian input potongan absen, } \\
\text { koperasi, makan, transport }\end{array}$ \\
\hline $\begin{array}{l}\text { Proses } \\
7.0^{*}\end{array}$ & $\begin{array}{l}\text { Nama Proses: Input Pinjaman } \\
\text { Masukan } \quad \text { : File Karyawan } \\
\text { Keluaran } \quad \text { : File Pinjaman } \\
\text { Proses } \quad \text { Membaca file Karyawan kemudian input pinjaman } \\
\text { kantin, telepon, perusahaan, lain-lain }\end{array}$ \\
\hline $\begin{array}{l}\text { Proses } \\
8.0^{*}\end{array}$ & $\begin{array}{l}\text { Nama Proses: Input Pengganti } \\
\text { Masukan : File Karyawan } \\
\text { Keluaran : File Pengganti } \\
\text { Proses : Membaca file Karyawan kemudian input uang cuti } \\
\text { yang diuangkan, Absen, Penyesuaian Gaji, dan Rapel Gaji }\end{array}$ \\
\hline $\begin{array}{l}\text { Proses } \\
9.1^{*}\end{array}$ & 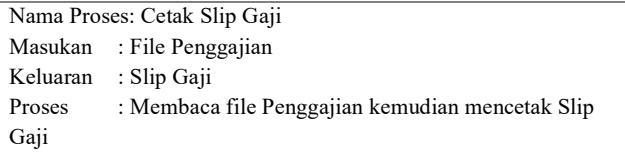 \\
\hline $\begin{array}{l}\text { Proses } \\
9.2^{*}\end{array}$ & $\begin{array}{l}\text { Nama Proses: Cetak Laporan Pembayaran Pajak PPh21 } \\
\text { Masukan: File Penggajian } \\
\text { Keluaran: Lap. Pembayaran Pajak PPh21 } \\
\text { Proses: Membaca file Penggajian kemudian mencetak Laporan } \\
\text { Pembayaran Pajak PPh21 karyawan. }\end{array}$ \\
\hline $\begin{array}{l}\text { Proses } \\
9.3^{*}\end{array}$ & $\begin{array}{l}\text { Nama Proses: Cetak SPT Tahunan } \\
\text { Masukan: File Penggajian } \\
\text { Keluaran: Laporan SPT Tahunan } \\
\text { Proses: Membaca file Penggajian kemudian mencetak SPT } \\
\text { Tahunan sesuai dengan format dari dinas perpajakan Indonesia. }\end{array}$ \\
\hline $\begin{array}{l}\text { Proses } \\
9.4^{*}\end{array}$ & $\begin{array}{l}\text { Nama Proses: Cetak Data Bulanan } \\
\text { Masukan: File Penggajian } \\
\text { Keluaran: Laporan Data Bulanan } \\
\text { Proses: Membaca file Penggajian kemudian mencetak Data } \\
\text { transaksi Penggajian selama satu bulan. }\end{array}$ \\
\hline $\begin{array}{l}\text { Proses } \\
9.5^{*}\end{array}$ & $\begin{array}{l}\text { Nama Proses: Cetak Laporan BPJS } \\
\text { Masukan: File Penggajian } \\
\text { Keluaran: Laporan BPJS } \\
\text { Proses: Membaca file Penggajian kemudian mencetak Laporan } \\
\text { pemotongan untuk BPJS }\end{array}$ \\
\hline $\begin{array}{l}\text { Proses } \\
9.6^{*}\end{array}$ & $\begin{array}{l}\text { Nama Proses: Cetak Laporan Pengobatan } \\
\text { Masukan: File Penggajian } \\
\text { Keluaran: Laporan Pengobatan } \\
\text { Proses: Membaca file Penggajian kemudian mencetak laporan } \\
\text { pengobatan karyawan dan tanggunan pengobatan. }\end{array}$ \\
\hline $\begin{array}{l}\text { Proses } \\
10.0^{*}\end{array}$ & $\begin{array}{l}\text { Nama Proses: Olah Penggajian } \\
\text { Masukan: File Karyawan, file Data Pokok, file Absensi karyawan, } \\
\text { file data Tunjangan Harian, file data bonus dan trip, file data } \\
\text { potongan, file data pinjaman, dan file data pengganti. } \\
\text { Keluaran: file penggajian } \\
\text { Proses: Membaca File Karyawan, file Data Pokok, file Absensi } \\
\text { karyawan, file data Tunjangan Harian, file data bonus dan trip, file } \\
\text { data potongan, file data pinjaman, dan file data pengganti } \\
\text { kemudian mengolah data penggajian karyawan. }\end{array}$ \\
\hline
\end{tabular}

\subsection{Entity Relationship Diagram (ERD)}

ERD pada sistem informasi Penggajian yang baru menunjukkan hubungan (relasi) antar entitas/obyek yang terlibat di dalam sistem. ERD ini nanti pada akhirnya akan menghasilkan struktur basis data yang sesungguhnya, yaitu desain tabel-tabel dan hubungan antar table yang akan disimpan pada media penyimpanan. Diagram ini juga akan kita gunakan dalam perancangan programnya.

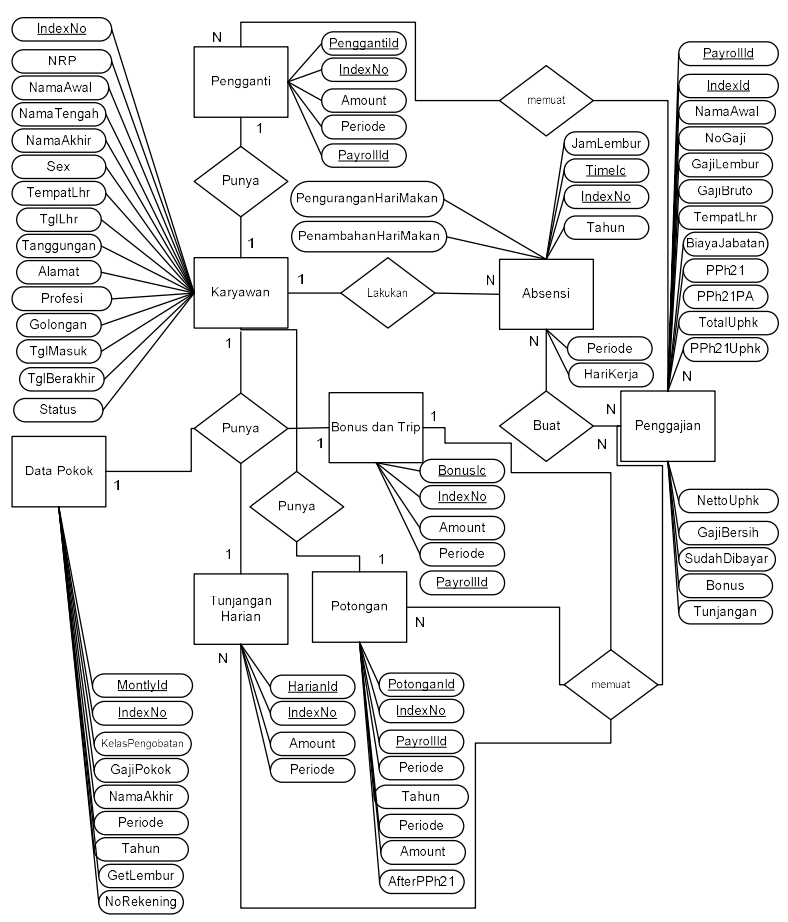

Gambar 6. Entity Relationship Diagram

\subsection{Rancangan Layar Masukan}

Rancangan formulir digunakan untuk media pengisian data yang menjadi acuan dalam memasukkan data kedalam layar masukan. Rancangan formulir diisi berdasarkan kententuan yang sudah ada dan kemudian di input kedalam sistem serta disimpan sebagai berkas. Karena ada banyak formulir, kami hanya menampilkan beberapa formulir pokok saja di sini

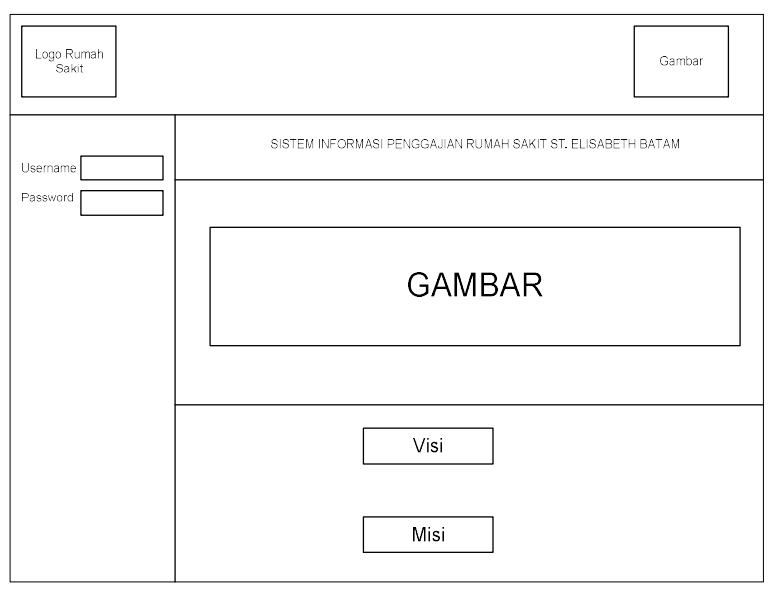

Gambar 7. Form login user 


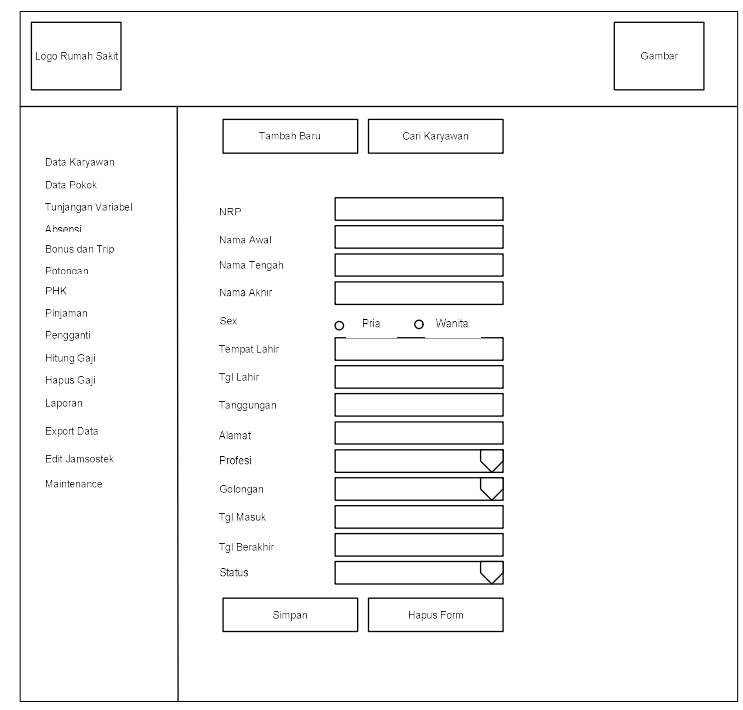

Gambar 8. Form Data Pokok

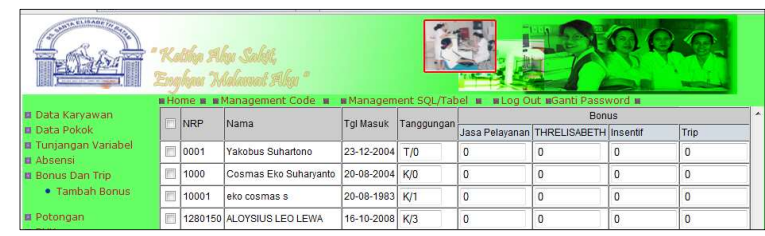

Gambar 9. Form bonus dan trip

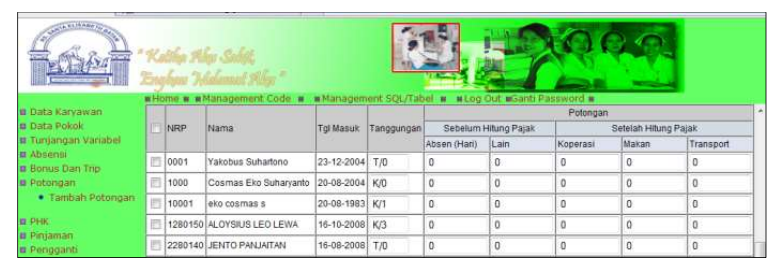

Gambar 10. Form Potongan

\subsection{Rancangan Laporan}

Bentuk laporan merupakan tampilan atau keluaran dari keseluruhan kegiatan yang dilakukan dalam suatu kegiatan. Desain ini digunakan untuk membuat suatu laporan yang menjadi keluaran ataupun hasil yang diinginkan dan juga alat komunikasi atau penghubung yang utama antara pemakai atau sistem komputer. Kami sajikan beberapa laporan pokok saja.

\section{Slip Gaji}

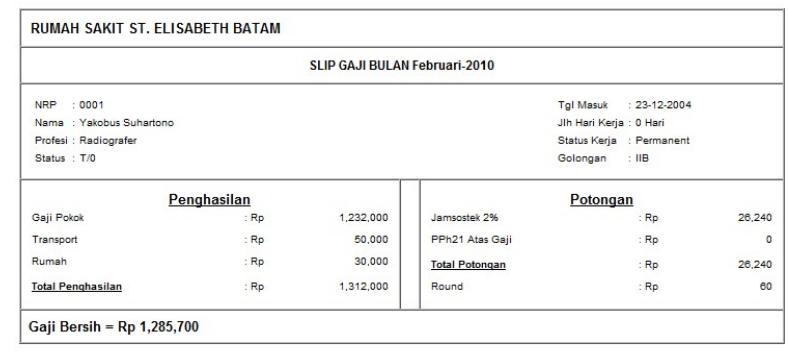

Gambar 11. Desain Slip gaji
2. Laporan Gaji Tahunan

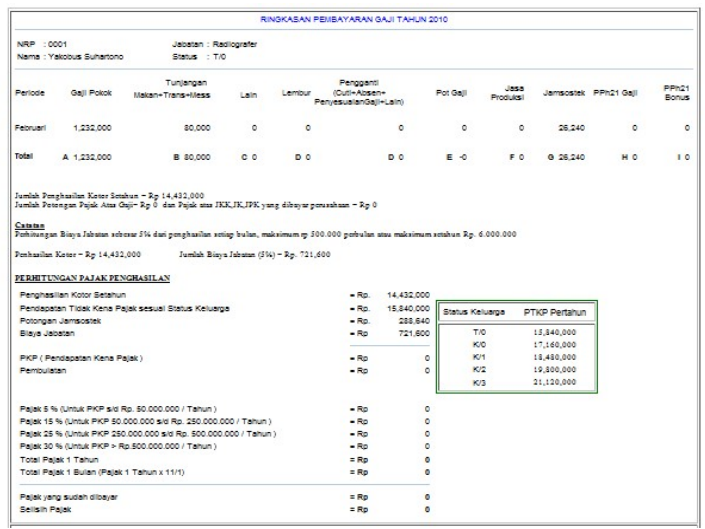

Gambar 12. Desain Laporan gaji tahunan

3. Laporan SPT Karyawan

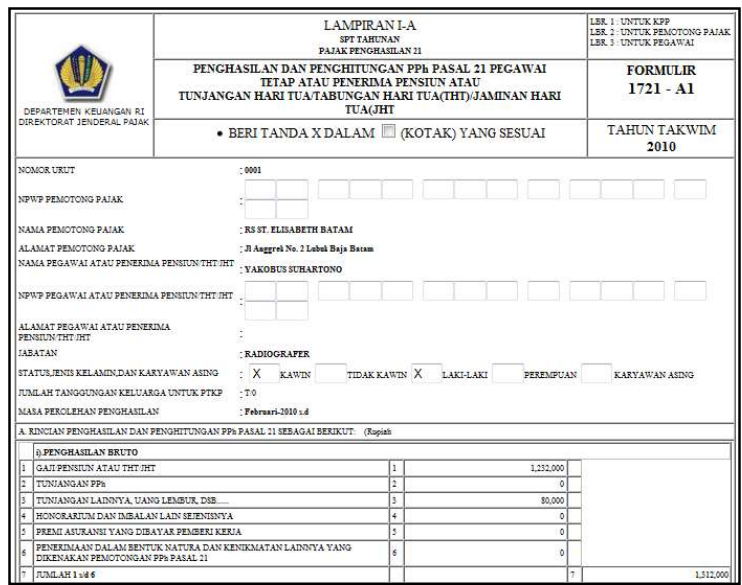

Gambar 13. Desain Laporan SPT Karyawan

4. Laporan SPT Rumah Sakit

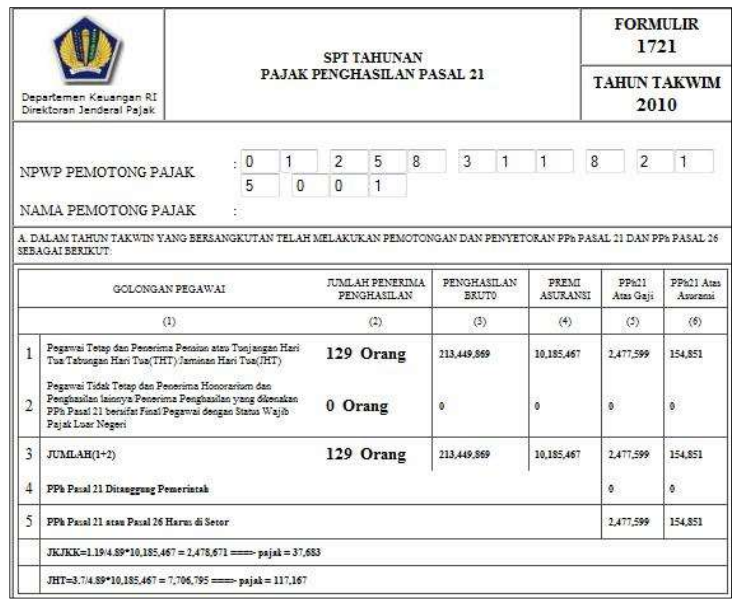

Gambar 14. Desain SPT Rumah Sakit 


\section{KESIMPULAN}

Berdasarkan pada analisis di atas yang penulis kerjakan melalui tahap-tahap dan prosedur penelitian, maka dapat diambil beberapa kesimpulan sebagai berikut:

1. Penggunaan teknologi khususnya sistem informasi masih sebagai support system dan belum menjadi prioritas strategis. Untuk mendukung sistem informasi rumah sakit yang modern maka perlu menjadikan teknologi informasi sebagai prioritas.

2. Dengan semakin berkembangnya industri di Batam terutama dalam memberikan jaminan kesehatan bagi para karyawannya, serta kesadaran masyarakat tentang kesehatan yang semakin meningkat, maka dengan adanya Sistem Informasi Penggajian, maka akan semakin memperlancar usaha-usaha untuk memanfaatkan peluang-peluang diatas, terutama dalam usaha-usaha kesejahteraan dan pelayanan kepada masyarakat.

3. Penerapan sistem berbasis web dengan pemrograman PHP dan database MySql akan mampu mengolah data penggajian sekaligus menyajikan laporan-laporan secara akurat dan cepat serta meminimalkan terjadinya kesalahan akibat kelalaian manusia. Efektifitas dan efisiensi sistem penggajian akan berdampak pada pelayanan rumah sakit yang lebih optimal.

4. Sistem informasi yang telah dirancang mampu menyelesaikan permasalahan yang dihadapi, DBMS mampu mengatasi redundansi data, dan integrasi tabletabel. Bahasa pemograman PHP dengan kolaborasi MySQL memampukan sistem informasi terintegrasi dan berbasis web yang dapat diakses dimana saja dan kapan saja.

5.

\section{DAFTAR PUSTAKA}

[1] P. S. Cosmas Eko Suharyanto, "Potential Threat Analysis Hypertext Transfer Protocol and Secure Hypertext Transfer Protocol of Public WiFi Users (Batam Case)," Int. J. Sci. Eng. Res., vol. 8, no. 3, pp. 320-326, 2017.

[2] E. C. Foster, Software Engineering, A Methodical Approach. New York, USA: Apress, 2014.

[3] L. Floridi, Information - A Very Short Introduction. Oxford: Oxford University Press, 2010.

[4] S. Gregor, "The Nature of Theory in Information Systems of Theory in Information Systems 1," MIS $Q$., vol. 30, no. 3, pp. 611-642, 2006.

[5] Y. H. Al-mamary, A. Shamsuddin, and N. Aziati, "The Role Of Different Types Of Information Systems In Business Organizations - A Review," Int. J. Res., vol. 1, no. 7, pp. 1279-1286, 2014.

[6] N. Manteghi and S. K. Jahromi, "Designing accounting information system using SSADM1 Case Study: South Fars Power Generation Management Company (S.F.P.G.M.C)," Procedia
Technol., vol. 1, pp. 308-312, 2012.

[7] https://dev.mysql.com/, "MySQL :: MySQL 5.7 Reference Manual :: 1.3.1 What is MySQL?" [Online]. Available: https://dev.mysql.com/doc/refman/5.7/en/what-ismysql.html. [Accessed: 03-May-2017].

[8] S. B. N. Ramez Elmasri, Fundamentals of Database Systems, 4th ed. San Francisco: Pearson, 2006.

[9] https://www.mysql.com, "MySQL :: About MySQL." [Online]. Available: https://www.mysql.com/about/. [Accessed: 03May-2017].

[10] php.net, "PHP: History of PHP - Manual." [Online]. Available: http://php.net/manual/en/history.php.php. [Accessed: 03-May-2017].

[11] K. C. Laudon and J. P. Laudon, Management Information Systems Managing the Digital Firm, vol. 2 , no. 1. 1968 .

[12] P. Vixie, Software Engineering Tutorial, Absolute Beginners. Tutorials Point (I) Pvt. Ltd, 2014.

[13] P. R. Indonesia, Undang-Undang Republik Indonesia Nomor 40 Tahun 2004 Tentang Sistem Jaminan Sosial Nasional. Indonesia, 2004, pp. 116.

[14] Dian Puspa, "PPh Pasal 21 (Pajak Penghasilan Pasal 21) | OnlinePajak." [Online]. Available: https://www.online-pajak.com/id/pph-pajakpenghasilan-pasal-21. [Accessed: 08-May-2017].

\section{BIODATA PENULIS}

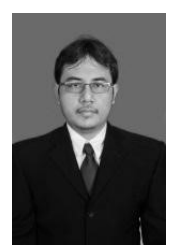

Cosmas Eko Suharyanto

Master of Information System Management, Bina Nusantara University, Jakarta 2015, Certified Cisco CCNA Instructor, Electrical Engineering and Information Technolgy Dept. Gadjah Mada University 2016, Lecturer of Computer Science at Putera Batam University,Batam. Email: costmust@gmail.com.

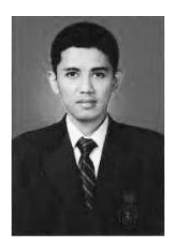

\section{Joni Eka Chandra}

Master of Engineering, Brawijaya State University, Surabaya, Indonesia. Lecturer of Computer Science at Putera Batam Universiy, Batam. Email: jonicandra82@gmail.com

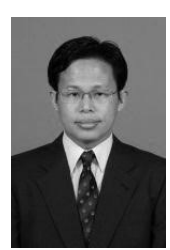

\section{Fergyanto E Gunawan}

Doctor of Engineering (Rompaku Program) Structural and System Engineering Toyohashi University of Technology, Toyohashi, Japan, Scopus ID : 6507898893, Senior Lecturer Binus Graduate Program, Bina Nusantara University, Jakarta. Email: f.e.gunawan@gmail.com 